\title{
The Shadow Banking System in the Euro Area: Definitions, Key Features and the Funding of Firms
}

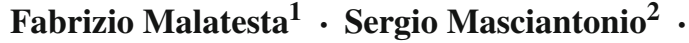 \\ Andrea Zaghini ${ }^{3}$
}

Received: 11 December 2015 / Accepted: 7 March 2016 / Published online: 21 March 2016

(C) Società Italiana degli Economisti (Italian Economic Association) 2016

\begin{abstract}
We investigate the size and evolution over time of shadow banks in the euro area, with a particular focus on their role in the funding of non-financial corporations (NFCs). Using an institution-based definition of shadow banks, which is consistent with available Eurosystem data, we find that, notwithstanding a significant heterogeneity across countries, the euro-area shadow banking system has grown in importance since the outburst of the global financial crisis. In addition, also its interconnectedness with the regulated banking system has increased over time. An econometric investigation shows that macroeconomic variables are the main determinants of the growth of loans to NFCs.
\end{abstract}

Keywords Shadow banks $\cdot$ Systemic risk $\cdot$ Financial crisis

JEL Classification G01 $\cdot \mathrm{G} 15 \cdot \mathrm{G} 21 \cdot \mathrm{G} 23$

\section{Contents}

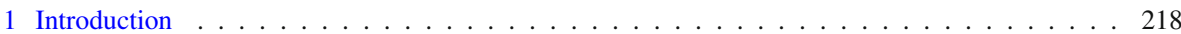

2 How to Single Out Shadow Banks: Alternative Approaches . . . . . . . . . . . . . . . . . . . . . . 220

3 Key Systemic Features of Shadow Banks in the Euro Area . . . . . . . . . . . . . . . . . . . . 223

3.1 Absolute Size . . . . . . . . . . . . . . . . . . . . . . . . . 223

3.2 Interconnectedness . . . . . . . . . . . . . . . . . . 226

$\bowtie$ Andrea Zaghini andrea.zaghini@bancaditalia.it

1 Facoltà di Economia, Università di Roma-Tor Vergata, Rome, Italy

2 European Commission, DG Financial Stability, Financial Services and Capital Markets Union, Brussels, Belgium

3 Bank of Italy, DG Economics, Statistics and Research, Via Nazionale 91, 00184 Rome, Italy 


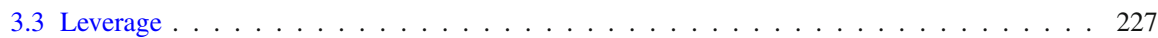

3.4 Maturity Mismatch . . . . . . . . . . . . . . . . . . . . . . . . 228

3.5 Cross-Country Heterogeneity . . . . . . . . . . . . . . . . . . . . . . . 230

4 Funding the Private Sector . . . . . . . . . . . . . . . . . . . . . . 231

4.1 Households Vs Non-Financial Corporations . . . . . . . . . . . . . . . . . . . 231

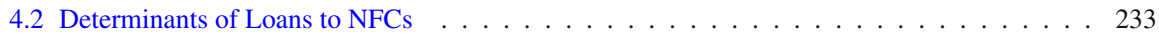

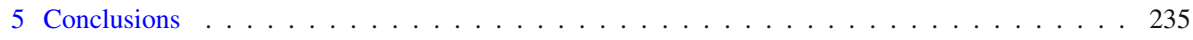

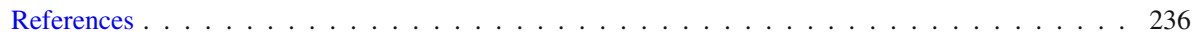

\section{Introduction}

Financial innovation has progressively transformed intermediation from a process concentrated in single financial institutions to a process broken down among several institutions, each characterized by a higher degree of specialization. Greater specialization has been associated to a significant reduction in the cost of intermediation, which in turn has pushed financial activity into the "shadow", as a way to reduce or eliminate the costs associated with prudential supervision and regulation, investor disclosure, and taxes (IMF 2014). In particular, the emergence of regulatory arbitrage opportunities has led to the development of a set of intermediaries performing banklike activities outside the perimeter of banking regulation, known as shadow banking system.

Shadow banking can complement traditional banking activity by enlarging access to credit, sustaining liquidity, and enabling better risk sharing, both in developing and advanced economies (Ghosh et al. 2012; Acharya et al. 2013; Gennaioli et al. 2013; Meeks et al. 2013). Indeed, shadow banking entities can conduct either all three or any one of the typical banking functions: maturity, credit and liquidity transformation. A significant additional function performed by shadow banking entities is the collateral intermediation function (Singh 2013b). Those entities were at the heart of the lengthening of the collateral and intermediation chain (Singh 2013a; Adrian and Shin 2010a). However, absent any adequate regulation, they may become more prone to assuming excessive risks; moreover, they do not have access to explicit safety nets, like the regulated banking sector. They may have also contributed to the excessive "elasticity" of the international financial system (Borio and Disyatat 2011; Borio 2014).

As the global financial crisis has revealed, these features made the shadow banking system particularly vulnerable to bank-like risks. Moreover, the interconnectedness with the regulated banking system gave rise to considerable systemic risks (European Commission 2014). Indeed, the complementarities between the two sectors were fostered by the integration of banking with capital markets (Adrian and Shin 2010a). In the run-up to the crisis, the shadow banking system grew considerably in size in many advanced economies, with a particularly pronounced trend in the US. This growth was characterized by the lengthening of the intermediation chain. Before the crisis, the financial intermediation process saw the intervention of multiple actors using a wider range of instruments. Securitization played a leading role in this process. The multiple steps of the intermediation chain allowed the gradual abatement of the own resources that were necessary to participate in the process. Moreover, liquidity, maturity and credit transformation were possible beyond the limits imposed to the banking 
system. Maturity and liquidity mismatches grew rapidly and contributed to the crisis of 2007-2009. This put the blame on the sector and gave rise to a considerable effort to monitor and regulate it.

The international financial community has been engaged since 2011 in a global effort to monitor and measure shadow banking, and to adapt the regulatory framework to better address shadow banking risks (FSB 2011). Nevertheless, even the identification of the shadow entities or the tracking of their activities is a non-trivial task. Attempts to provide a measure of shadow banking activities have been made by the Financial Stability Board itself (2011), ESMA (2013), Pozsar et al. (2010), Bouveret (2011), Bakk-Simon et al. (2012) among others. But none of these contributions can be considered conclusive.

In this light, the paper has three main objectives. The first is to review the main definitions of the shadow banking system. In particular, we describe four approaches provided by academics and institutions: two of them are based on the activities undertaken by financial institutions and two are instead based on the nature of the institutions themselves. The second aim of the paper is to employ one of such measures to assess the evolution of the interlinkages between banks, shadow banks and the real sector of the economy in the euro area. Finally, given the relevance for the real sector of the shadow banks as a source of funding, we propose an empirical analysis of the main determinants of the loans granted to non-financial corporations (NFCs) over the period 1999Q1-2014Q1.

To preview our results, by relying on the definition proposed by ECB staff (BakkSimon et al. 2012) — which is based on an adjustment of the standard "other financial institutions" (OFI) sector-we show that the euro-area shadow banking system expansion has not been stopped by the financial crisis and it has significantly grown in both absolute and relative terms. While in 1999 total assets of shadow banks were 21 traditional and shadow banks, in 2014 they were $30 \%$.

Moreover, we report evidence that the interlinkages with the banking sector have strengthened after the global financial crisis. Since 2007 the share of deposits held with euro-area traditional banks by shadow banks has increased by $8 \%$ points, reaching $23 \%$ at the beginning of 2014. In addition, around half of such deposits have a maturity below 1 year.

At the same time, while it is too early to speak of a substitution effect taking place in the funding of NFCs, the share of loans from shadow banks has more than doubled since 1999. A comparison with the traditional bank loans shows that the main determinants are slightly different, with shadow banking loans being influenced more than banks by macroeconomic variables.

The rest of the paper goes as follows. In Sect. 2 we describe the main definitions of shadow banking and show that only one is fully compatible with euro-area current data availability; in Sect. 3 we implement the chosen approach and we provide, albeit with some caveats, an assessment of the dimension of the shadow banking system in the euro area, of its developments throughout the crisis and of its interlinkages with regulated banks; in Sect. 4 we look at the role of the shadow banks as sources of funding for households and NFCs; in Sect. 5 we draw some conclusions. 


\section{How to Single Out Shadow Banks: Alternative Approaches}

While the list of definitions of the shadow baking system is already quite long, ${ }^{1}$ they can be classified into two main sets: those based on the types of financial institutions, and those based on the activities undertaken by financial institutions. In this section we will review four definitions, two based on the activities undertaken (Pozsar et al. 2010; IMF 2014) and the other two based on the features (activities) of the institutions themselves (FSB 2011; Bakk-Simon et al. 2012).

According to Pozsar et al. (2010)'s definition, the shadow banking system is a web of specialized financial institutions that channel funding from savers to investors through a range of securitization and secured funding techniques. Although shadow banks conduct credit and maturity transformation similar to that of traditional banks, they do so without the direct and explicit public sources of liquidity and tail-risk insurance available through the access to the central bank funding and the deposit insurance. Shadow banks are therefore inherently fragile, not unlike the commercial banking system prior to the creation of the public safety net.

Even though shadow banking activity does not benefit from an official publicsector enhancement, it might receive some kinds of support: indirect supports and/or implicit supports. In particular, official enhancement to credit intermediation activities can be classified into five levels of strength. According to the kind of enhancement received, Pozsar et al. (2010) determine the shadow banking system. The levels of official enhancement are as follows: (1) direct and explicit; (2) direct and implicit; (3) indirect and explicit; (4) indirect and implicit; (5) unenhanced.

In particular, a liability with direct official enhancement must be on a regulated financial institution's balance sheet, whereas off-balance sheet liabilities of financial institutions might only indirectly receive a support from the public sector.

As concerns the direct support, activities with direct and explicit official enhancement include on-balance sheet funding of depository institutions, insurance policies, liabilities of defined benefit pension funds, and debt guaranteed through public sector programs. Activities with direct and implicit official enhancement include debt issued or guaranteed by the government-sponsored enterprises (GSEs) and other institutions, which benefit from an implicit credit put option from the taxpayer. The implicit nature of support implies that the intermediary receives the benefit of credit put options from the public sector, but typically would not pay their full marginal social cost. This kind of government support is also known as the too-big-too-fail syndrome (Mishkin 2006).

Also activities with an indirect support can be divided into two groups (indirect and explicit, indirect and implicit). Activities with indirect and explicit official enhancement generally include the off-balance sheet activities of depository institutions, such as unfunded credit card loan commitments and lines of credit to conduits. At the same time, activities with indirect and implicit official enhancement include asset management activities such as bank-affiliated hedge funds and money market funds (MMFs), as well as the securities lending activities of custodian banks. While financial intermediary liabilities with an explicit enhancement benefit from official sector put option,

\footnotetext{
${ }^{1}$ See Adrian and Ashcraft (2012) and Fein (2013) for excellent surveys.
} 
liabilities enhanced with an implicit credit put option might not benefit from such enhancement ex-post.

Finally, the last class of official enhancement proposed by Pozsar et al. (2010) is made of all unenhanced activities. According to the authors, only the first class of activities - undertaken by banks and insurance corporations and pension funds (ICPF) - is not part of the shadow banking system.

It is worth noting that Pozsar et al. (2010) propose two measures of the shadow banking system for the US (net and gross), both computed from the Federal Reserve's "Flow of Funds" data. The net measure attempts to remove all possible double-counting and as such, it is a closer measure of the net supply of credit provided by shadow banking activities. However, the holding of shadow liabilities by institutions inside the government safety net makes it difficult to draw unambiguous boundaries between traditional and shadow credit intermediation (Eichner et al. 2015).

A second definition of shadow banking based on financial institution activities has been recently proposed by the IMF (2014) in the Global Financial Stability Report. The definition hinges on a distinction between "core" and "noncore" liabilities. The core liabilities are defined as the funding that banks (and marginally MMFs) traditionally draw on: the regular deposits of ultimate creditors (resident households, nonfinancial corporations, state and local government, insurance corporations, pension funds, nonMMFs investment funds).

Noncore liabilities encompass all sources of funding that fall outside the core liability definition. The main financial instruments that are considered to be components of noncore liabilities are debt securities, loans, MMF shares, and a small portion of restricted deposits. The issuers of noncore liabilities are all the financial intermediaries (including banks) except insurance companies, pension funds, and non-MMF investment funds, while the holders consist of the ultimate creditors plus the foreign sector. The noncore liabilities approach does not distinguish between the institutions that issue the liabilities, it rather focuses on funding sources different from deposits. For example, it captures on-balance sheet securitization by banks, including covered bonds, whereas other measures do not.

The noncore liabilities measure can be constructed to include intra-financial sector positions (the broad measure) or exclude them (the narrow measure). The distinction between the two measures is based only on the counterparts: the narrow measure includes only ultimate creditors and nonresidents as counterparts, whereas the broad measure also includes issuers' positions vis-à-vis financial institutions not included among the ultimate creditors (i.e. institutions different from insurance companies, pension funds, and non-MMF investment funds).

The challenge with the activity-based approach is that it might not keep up with financial innovation. In fact, while one can come up with a list of shadow banking activities today, it is unclear where such a list would capture shadow banking activities and risks that may arise in the future (Adrian et al. 2013; Claessens and Ratnovki 2014). Thus a more pragmatic approach is to start from the nature of the financial institutions themselves.

The "official" definition formulated by the FSB (2011) states that the shadow banking system is "the system of credit intermediation that involves entities and activities outside the regular banking system”. In the words of the FSB: “...this implies focusing 
on credit intermediation that takes place in an environment where prudential regulatory standards and supervisory oversight are either not applied or are applied to a materially lesser or different degree than is the case for regular banks engaged in similar activities". In addition, the FSB encourages authorities to take a practical two-step approach in identifying the shadow banking system: (1) authorities should cast the net wide, looking at all non-bank credit intermediation to ensure that data gathering and surveillance cover all areas where shadow banking-related risks to financial stability may potentially arise; (2) authorities should narrow the focus to the subset of nonbank credit intermediation where there are developments that increase systemic risk (maturity/liquidity transformation, imperfect credit risk transfer and leverage) and/or indications of regulatory arbitrage undermining the benefits of financial regulation.

Thus, the primary focus of the FSB's monitoring exercise is a "macro-mapping", based on balance sheet data of national financial accounts (integrated with other national sources), that looks at all non-bank financial intermediation. This broad estimate, referred to as the Monitoring Universe of Non-Bank Financial Intermediation (MUNFI), ensures that data gathering covers the areas where shadow banking-related risks to the financial system might potentially arise. In addition, the FSB refines the shadow banking measure by also reporting a narrower measure of the MUNFI estimate. $^{2}$

In the annual report, the FSB includes data from 25 jurisdictions and the euro area as a whole, bringing the coverage of the monitoring exercise to about $80 \%$ of GDP and $90 \%$ of global financial system's assets.

More recently, the FSB - through its Workstream on Other Shadow Banking Entities, WS3 - is developing a forward-looking high-level policy framework for shadow banking entities other than MMFs. In particular, they acknowledge that shadow banking may take different forms across jurisdictions due to different legal and regulatory settings, as well as the constant innovation and dynamic nature of the non-bank financial sectors. By focusing on the underlying economic functions rather than legal forms, this framework allows authorities to assess shadow banking activity in non-bank financial entities in a consistent manner and be forward-looking and capture additional types of entities, including new structures and innovations within these economic functions (Table 1).

Following the FSB definition based on financial institutions described above, ECB staff (Bakk-Simon et al. 2012) adjusts it in order to properly fit the data availability for the euro area. They propose an aggregate for the shadow banking system which is a variation of the institutional sector in Eurosystem's financial accounts labelled "Other Financial Intermediaries" (OFIs). The authors call this new aggregate "other intermediaries", as opposed to the traditional "banks" aggregate. The OFIs sector comprises all financial institutions other than those included in the monetary financial institu-

\footnotetext{
2 In practice, the narrowing down of the broad MUNFI set of financial institutions is carried out by subtracting from the broad definition: (a) entities that are prudentially consolidated into a banking group; (b) entities not directly involved in credit intermediation, including Equity Investment Funds and equity REITs; (c) entities that are part of a non-financial group and are created for the sole purpose of performing intra-group activities; (d) entities related to self-securitization, which is defined as those securitization transactions done solely for the purpose of using the securities created as collateral with the central bank in order to obtain funding.
} 
Table 1 Shadow banking according to economic functions

\begin{tabular}{|c|c|c|}
\hline $\begin{array}{l}\text { Economic } \\
\text { function }\end{array}$ & Definitions & Examples of classified entity types \\
\hline EF1 & $\begin{array}{l}\text { Management of collective investment } \\
\text { vehicles with features that make them } \\
\text { susceptible to runs }\end{array}$ & $\begin{array}{l}\text { Credit hedge funds, fixed income mutual } \\
\text { funds, trust companies }\end{array}$ \\
\hline $\mathrm{EF} 2$ & $\begin{array}{l}\text { Loan provision that is dependent on } \\
\text { short-term funding }\end{array}$ & Finance companies, leasing companies \\
\hline EF3 & $\begin{array}{l}\text { Intermediation of market activities that is } \\
\text { dependent on short-term funding or on } \\
\text { secured funding of client assets }\end{array}$ & Broker-dealers \\
\hline EF4 & Facilitation of credit creation & $\begin{array}{l}\text { Mortgage insurers, financial guarantors, } \\
\text { insurers that write credit protection }\end{array}$ \\
\hline EF5 & $\begin{array}{l}\text { Securitisation-based credit intermediation } \\
\text { and funding of financial entities }\end{array}$ & CLOs, ABCP, SIVs \\
\hline
\end{tabular}

Source: FSB (2014), Global shadow banking monitoring report

tions' sector (the socalled MFIs, including euro-area central banks, credit institutions, and MMFs) and the insurance corporations and pension funds sector (ICPFs).

The construction of the OFI sector is therefore residual and covers not only institutions that may well be considered shadow banks, but also intermediaries for which such a classification would be questionable, such as regulated investment funds. Conversely, it excludes intermediaries like MMFs which are engaged in activities that can be considered as shadow banking. In order to circumvent this drawback, the shadow banking aggregate proposed by Bakk-Simon et al. (2012), is made by the OFI sector plus Money Market Funds (MMFs) minus investment funds other than MMFs. All in all, the definition differs from that of the FSB by not considering as shadow banks the investment funds.

It is worth underlying that the ECB's proxy for the shadow banking system of the euro area is not fully comparable with the measure provided, for instance, by Pozsar et al. (2010) for the United States. One important difference is that the information from the US Flow of Funds allows for a more granular breakdown of the liabilities of the different institutional sectors, allowing the building of an aggregate for the shadow banking system which covers only those liabilities that are a close substitutes for traditional bank liabilities (e.g., open market paper, repo, etc.).

In the quantitative analysis carried out in the next sections, as working definition of the euro-area shadow banking system we use the "other intermediaries" aggregate whenever possible, and the OFI sector otherwise.

\section{Key Systemic Features of Shadow Banks in the Euro Area}

\subsection{Absolute Size}

Figure 1 plots the total assets of banks and shadow banks in the euro area and the US. For comparability purposes, shadow banks are defined according to Bakk-Simon 


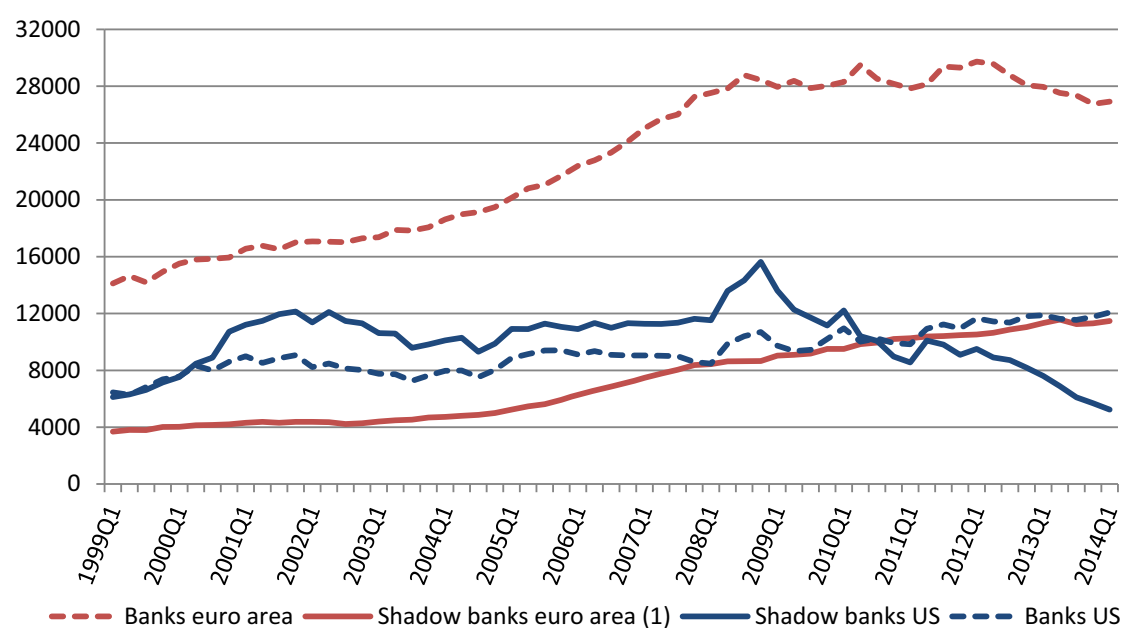

Fig. 1 Assets of banks and shadow banks in the euro area and the US (billions of euro). Sources: euro area accounts (ECB and Eurostat) and monetary statistics (ECB), financial accounts of the United States. (1) Shadow banks is the aggregate made by OFIs plus MMF minus investment funds other than MMF

et al. (2012)'s other intermediaries definition. The comparison highlights a number of striking differences between the euro area and the US. A first difference is that, at the beginning of 2014 both sectors were much larger (in terms of total assets) in the euro area than in the US. Banks managed 27 trillions of euros in the euro area and 12 trillions in the US, while shadow banks managed 11 trillions in the euro area and 6 trillion in the US. These numbers suggest a much larger reliance on financial intermediation in the euro area, with respect to the US; the other side of the coin being a larger role played by the bond market in the US. A second difference is that, differently from the US, were the size of shadow banks grew well above that of regulated banks in the decade preceding the global financial crisis, in the euro area the dimension of the shadow banking system has always been by far smaller than that of banks. A third difference is that, while in the US the size of the shadow banking sector has been consistently declining since the second quarter of 2009, in the euro area shadow banks' total assets grew at sustained rates in the run-up to the crisis and continued to increase afterwards, even though at a slower pace, reaching the maximum at the end of the sample. A fourth difference is that, after the deleveraging of 2009-2010, bank's total assets in the US started a new upward trend, while in the euro area total assets levelled off below $€ 30$ trillion over the first wave of the global financial crisis and then started declining from the second quarter 2012. As a result of these trends, as a ratio of banks' total assets, shadow banks' total assets in the euro area increased from $26.1 \%$ in 1999 to $30.9 \%$ in 2007 , to reach $42.6 \%$ in the first quarter 2014, suggesting a possible substitution of bank financing of the economy with non-bank financing. In the US the same ratio was $124.8 \%$ in 2007 and declined to $48.3 \%$ in the first quarter of 2014.

As for the United States, it is important to observe that the evidence about the size of the shadow banking system shown in Fig. 1 (based on the notion of other 


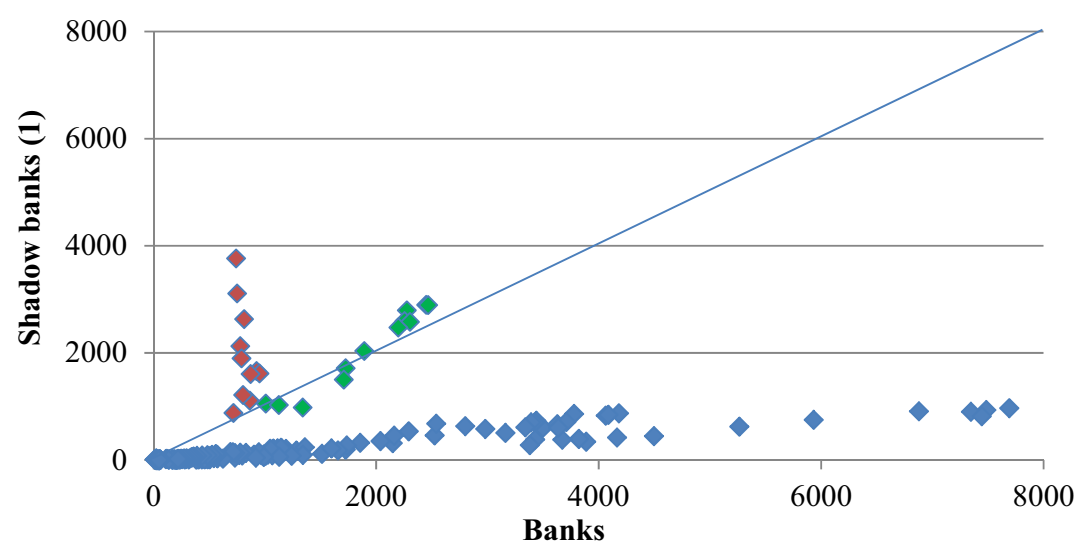

Fig. 2 Assets of banks and shadow banks by country (trillions of euros). Sources: euro area accounts (ECB and Eurostat) and monetary statistics (ECB). (1) Shadow banks is the aggregate made by OFIs plus MMF minus investment funds other than MMF. Each diamond indicates the amount of banks and shadow banks assets in a specific year, for each year from 2005 to 2014. Green diamonds the Netherlands; red diamonds Luxembourg; blue diamonds all other euro-area countries (excluding Germany, due to data availability) (color figure online)

intermediaries) is consistent with what emerges when using the measure proposed by Pozsar et al. (2010). In fact, Pozsar et al. (2013) shows that shadow banks' liabilities exceeded that of traditional banks in the mid-'90s and grew at higher rates until the outburst of the financial crisis, with a peak in early 2008; thereafter they dramatically dropped, to become smaller than banks' liabilities in 2011. However, the evidence for the US provided by IMF (2014) and the FSB, which rely on broader measures, shows a growing difference from 2008, highlighting a significant rebound of the size of the US shadow banking sector. This difference can be explained through the shift of shadow banks to less well-monitored activities not captured by our measure.

By focusing on cross-country heterogeneity within the euro area, Fig. 2 shows a scatter plot of the dimension of both systems in each year for each country. ${ }^{3}$ The size of the shadow banking system seems only weakly correlated with the dimension of the traditional banking system. Most of the points lay well below the main diagonal, suggesting that in almost all euro-area countries the size of shadow banks is far lower than that of regulated banks and that the expansion of bank finance is associated to a less than proportional increase in shadow banking. Yet, there are two notable exceptions to this common framework: the Netherlands (green diamonds) and Luxembourg (red diamonds). For the former the evolution of shadow banks seems to be linked almost one-to-one with that of traditional banks, while in Luxembourg the shadow banking system is almost independent of the size of traditional banks. ${ }^{4}$

\footnotetext{
3 Germany is excluded due to lack of data availability. See also Sect. 3.5.

4 This should not come as a surprise. Indeed, Luxembourg is the European hub for the fund management industry and much of the growth in its shadow banking sector is more likely to be connected to that.
} 


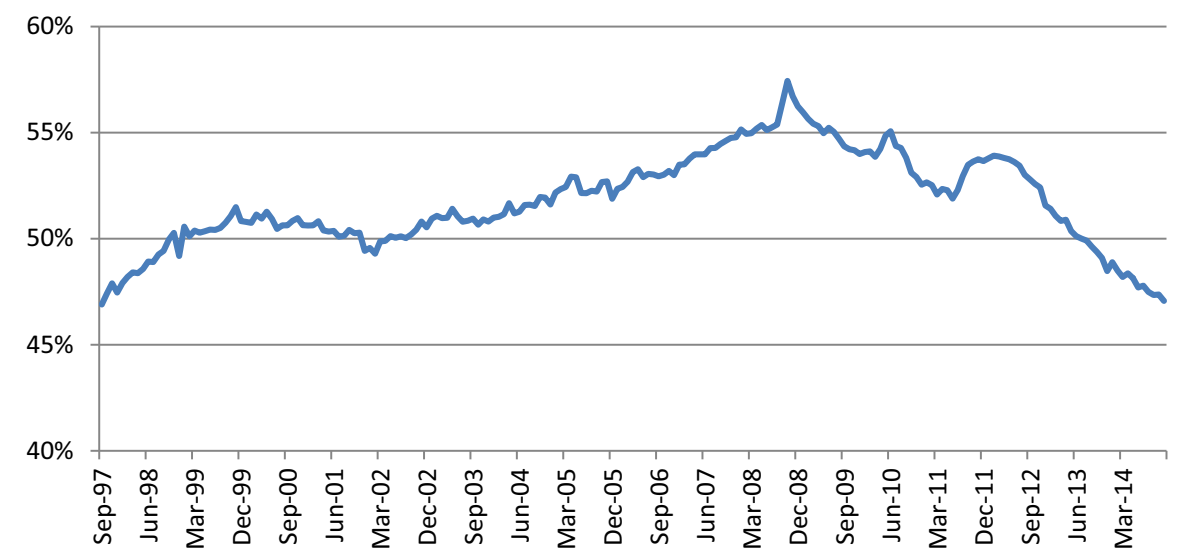

Fig. 3 Financial sector's deposits with MFIs (\%). Sources: ECB monetary statistics

\subsection{Interconnectedness}

In addition to size, another important aspect of the evolution of the financial system is the interrelations between banks and shadow banks. Figure 3 plots the share of financial sector's deposits held with euro-area banks. Financial sector's deposits with euro-area banks increased steadily relative to deposits from the non-financial sector from 1997 to mid-2008 (with the exception of the 2000-2001 period), but thereafter a trend reversal occurred. Given that the majority of financial sector's deposits are constituted by deposits held by credit institutions, this change in trend may be easily explained by the interbank market disruption that ensued the Lehman Brothers' bankruptcy. Afterwards, the trend gained new strength during the second wave of the crisis, which in the euro area took the form of a sovereign debt crisis. Another possible explanation can be related to the changing collateral space (Singh 2013a). Indeed, collateral intermediation often entails an exchange with deposits. Therefore, the decrease in the availability of high-quality collateral since the eruption of the financial crisis and the decrease in its re-use (Singh 2013a,b) may have negatively affected the collateral intermediation chain and the development of intra-financial system deposits.

Nevertheless, the composition of financial sector's deposits by type of intermediary suggests the share of shadow banks has increased from about $15 \%$ just before the eruption of the global financial crisis (2006) to almost $23 \%$ in $2014 .^{5}$

As for the type of instrument, more than half of shadow banks' deposits are overnight and with maturities of less than 1 year (Fig. 4). Presumably the portion of short-term financing is even greater, because a significant amount of repo transactions is not included in the OFIs statistics (Bakk-Simon et al. 2012).

\footnotetext{
5 In this case, the use of the OFI sector instead of "other intermediaries" implies an approximation in the estimation of shadow banks' deposits. This is because the OFI sector also includes non-MMF investment funds which hold a small (though non negligible) amount of bank deposits. The absence of MMFs instead is not relevant, since they do not hold deposits. All in all the figure is likely to be just slightly overestimated.
} 


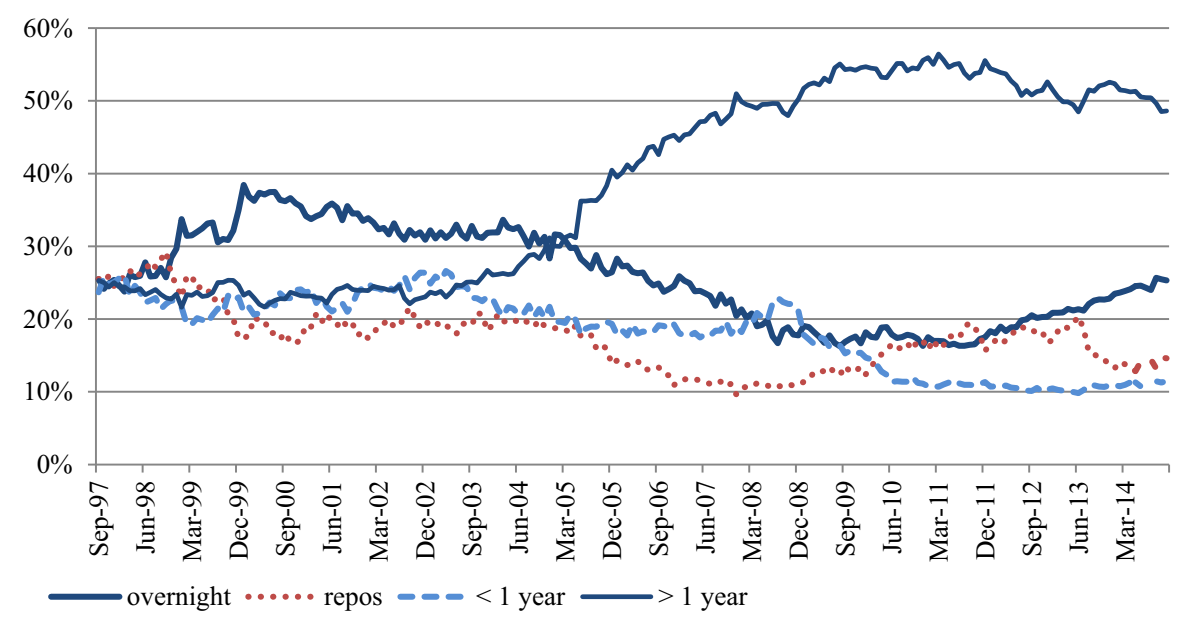

Fig. 4 Shadow banks deposits by instrument in the euro area (1) (\%). Sources: ECB monetary statistics. (1) Shadow banks are proxied by the OFI sector

In conclusion, although banks' reliance on funding from the financial sector has dropped by $10 \%$ since October 2008, there has been a relative increase in the share of financing from the shadow banking system. Therefore, the role of shadow banking entities in collateral intermediation is likely to have increased with respect to credit institutions. Moreover, this funding is mainly short-term and therefore more susceptible to runs and the drying-up of liquidity. On the whole, these indicators signal an increased interconnectedness between the regulated banking system and the shadow banking system, implying a greater risk of contagion through the transmission of shocks from unregulated intermediaries to traditional banks.

\subsection{Leverage}

An important feature of financial intermediation activities is the use of leverage. As for maturity transformation, high leverage is a powerful amplification mechanism in stress situations and therefore a potential source of systemic risk that needs to be monitored (Adrian and Shin 2010b). That is why the FSB recommends controlling for its presence outside the regulated banking sector.

The indicator of leverage presented in Fig. 5 is computed as the ratio of total assets to equity. As expected, the leverage is higher for banks (left-hand axis) than shadow banks (right-hand axis), as deposits constitute the main source of financing for MFIs. Anyway the pattern of the leverage for the shadow banking sector shows a development broadly in line with that of the banking sector. In the early $2000 \mathrm{~s}$ its leverage significantly increased, and then it slightly decreased until mid-2007 in agreement with the asset price inflation of those years. Leverage then increased during the first phase of the global financial crisis and peaked in January 2009, a few months after Lehman Brothers' demise. Then a downward trend is clearly visible in the data for both banking and shadow banking sectors. Since then the leverage of traditional banks has declined by $35 \%$ (from 23.4 in January 2009 to 15.2 in January 2014). Over 


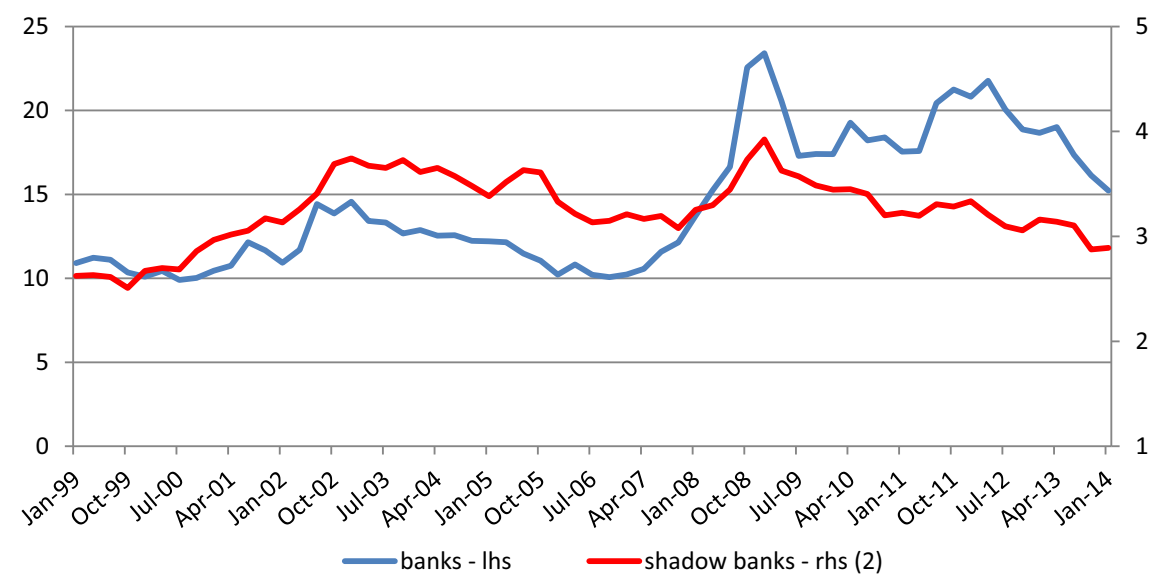

Fig. 5 Leverage of banks and shadow banks (1). Sources: ECB euro area accounts. (1) Leverage is the ratio of total assets over equity. (2) Shadow banks is the aggregate made by OFIs plus MMF minus investment funds other than MMF

the same period, the leverage of shadow banks, although being substantially lower, had a slightly less sizeable decline (26\%, dropping from 3.9 to 2.9). Thus, in terms of leverage, the systemic riskiness of the euro-area shadow banking system has declined, although less that proportionally with respect to the banking sector.

\subsection{Maturity Mismatch}

Maturity transformation is another defining feature of the banking industry. In situation of stress, maturity mismatches can act as a major amplification mechanism and thereby foster systemic risk. This can be particularly the case if maturity transformation takes place in institutions that are not subject to the same stringent capital and liquidity requirements of traditional banks. Unfortunately, the ECB Statistical Data Warehouse is not designed to provide an accurate picture of maturity mismatches. First, available breakdowns refer to maturity at inception rather than to residual maturity, and so they do not properly show current balance-sheet maturity vulnerabilities. Second, not all financial instruments are broken down by maturities, so the analysis is often incomplete or based on assumptions on the maturity structure of sizeable parts of the balance sheet.

Despite these difficulties, it is possible to provide some evidence on the issue. Figure 6 shows the maturity mismatch in the regulated banking system and in the shadow banking system. Maturity of assets and liabilities refers to the original maturity or, for those instruments for which maturity breakdown is not available, it is estimated using the standard assumptions of the ECB's statistics. ${ }^{6}$

\footnotetext{
6 Short-term assets/liabilities include currency, all deposits, short-term debt securities, short-term loans, financial derivatives, quoted shares, mutual fund shares and other accounts receivable/payable. All other financial instruments are included in long-term assets/liabilities. As a caveat, it must be noted that, for shadow banks, maturity mismatches might be slightly underestimated, because the OFI sector (which is
} 

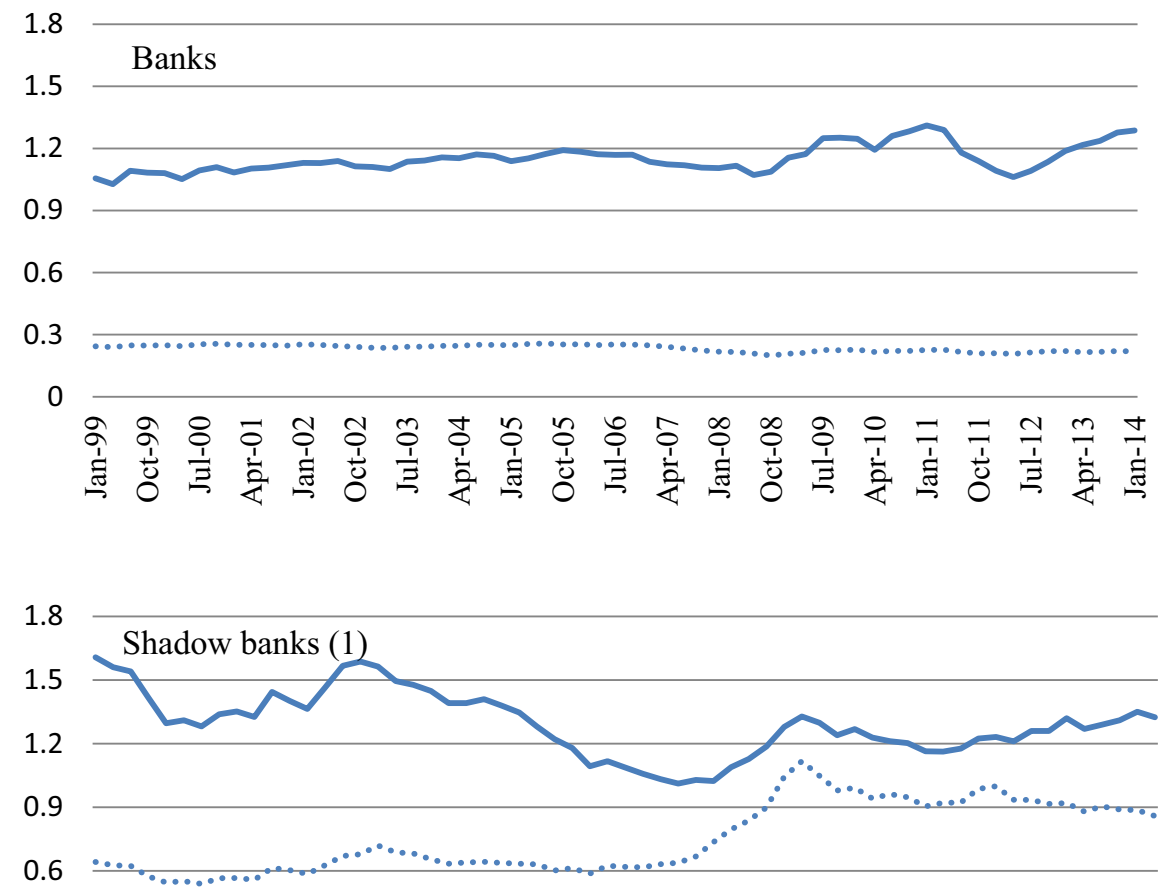

0.3

0

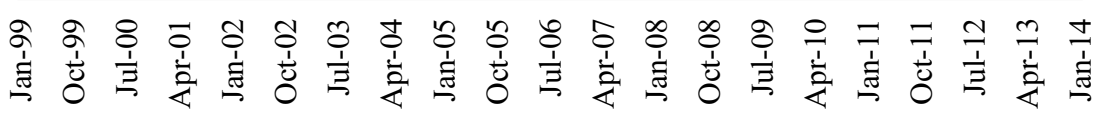

$$
\begin{aligned}
& \text { long term/short term assets } \quad . . . \text { long term/short term liabilities }
\end{aligned}
$$

Fig. 6 Maturity structure of assets and liabilities of banks and shadow banks. Sources: ECB euro area accounts. (1) Banks are proxied by the MFI sector and shadow banks by the OFI sector

An indicator of maturity mismatch is the gap between the long-term/short-term assets ratio and the long-term/short-term liabilities ratio. Banks run a large maturity mismatch, as is to be expected given their function in the credit intermediation chain. The structure of their assets is fairly balanced (ratio close to 1), while their liabilities are mostly M3 components, including short-term and liquid deposits.

With regard to the shadow banking sector instead, long-term instruments represent a larger fraction of both assets (especially before 2006) and liabilities. It is interesting to note that the burst of the global financial crisis forced shadow banks to sharply increase the amount of long-term funding, due to panic selling in repo and money

Footnote 6 continued

used instead of the other intermediaries sector) also includes investment funds, which usually do not run maturity mismatches, while it excludes the MMFs which do undertake maturity transformation. On the contrary, for banks maturity mismatches might be slightly overestimated, as MFIs comprise the central bank and the MMFs. 


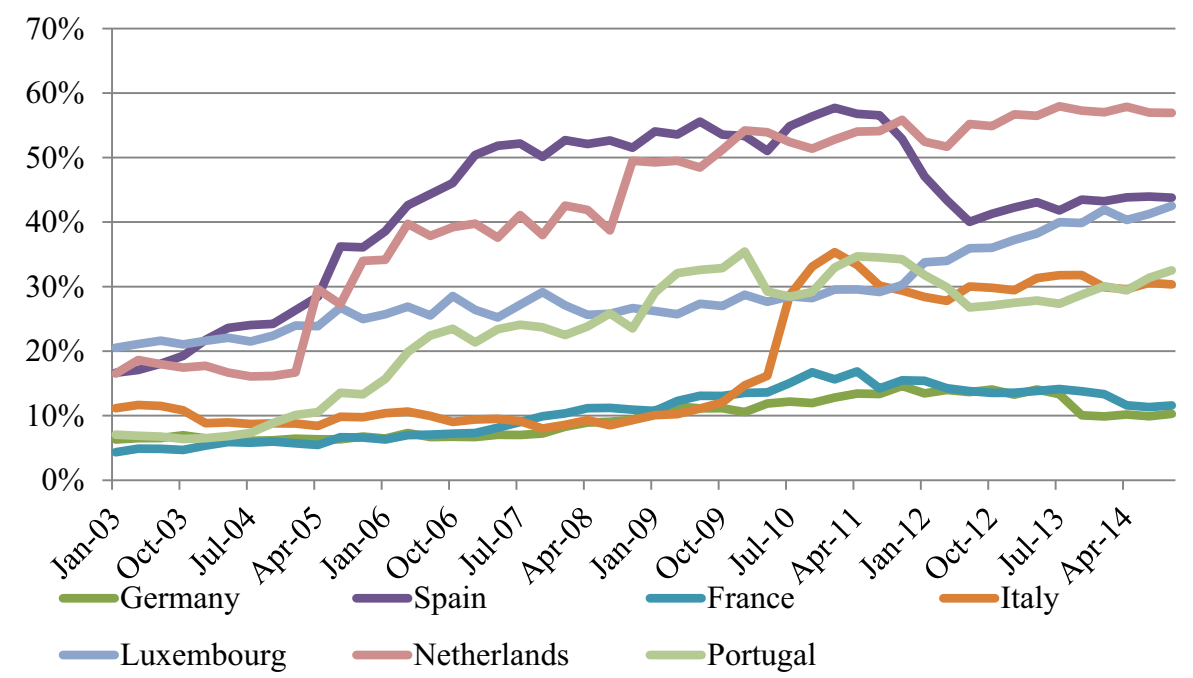

Fig. 7 Deposit with euro-area banks held by shadow banks (1) (\%). Sources: ECB monetary statistics. (1) Shadow banks are proxied by the OFI sector

markets. But after the Lehman Brothers bankruptcy the gap between the maturity of assets and that of liabilities has slightly widened again. In particular, in 2011 the share of long-term to short-term assets started to grow again, albeit moderately. This increase points to a more illiquid asset side, potentially more exposed to costly fire sales in case of market turmoil.

\subsection{Cross-Country Heterogeneity}

In the euro area, a further difficulty in assessing the role and the interconnectedness of the shadow banking system is the different importance of shadow banks across countries. Insights into the degree of interconnectedness between banks and shadow banks in euro-area countries can be gained by looking at the shadow banks' deposits held with euro-area MFIs (Fig. 7). ${ }^{7}$

Bearing in mind that the size of the financial sector differs across euro-area countries, a common trend emerges over time. The share of shadow banks' deposits held with banks increased in all euro-area countries until the outset of the most acute phase of the sovereign debt crisis in mid-2011. Then the share stabilized or slightly declined in all countries but Luxembourg and the Netherlands. In 2013-2014 it stood everywhere at levels well above those recorded before 2007. The share of shadow banks deposits for the Netherlands became the largest of the euro area in the second half of

\footnotetext{
7 In other words, we look at the country breakdown of the euro-area share reported for shadow banks in Fig. 4.
} 
2011 surpassing Spain, while in Luxembourg the share increased from below $30 \%$ before the burst of the global financial crisis to $42 \%$ in $2014 .{ }^{8}$

All in all, this preliminary evidence suggests a considerable reliance of banks financing on the shadow banking sector, and thus a significant degree of interconnectedness between the two sectors. Data also highlights a high heterogeneity of euro-area countries in terms of degree of banks' dependence from shadow banks' deposits, which can be partly explained by the differences in domestic financial market structures.

\section{Funding the Private Sector}

\subsection{Households Vs Non-Financial Corporations}

In this section we analyze the contribution of the shadow banking system to the financing of households and NFCs. Non-bank channels of financing of the real economy are important because they increase the overall amount of available financial resources and their diversification. However, non-bank financing can also be a source of systemic risks, as the global financial crisis has clearly shown (FSB 2014). It is thus worth analyzing how the composition of household and corporate finance has evolved over time. In particular, we focus on one single source of financing: loans from traditional banks and shadows entities. This implies that at this stage we neglect other sources like bonds and direct holding of shares, which may have an important role, especially for NFCs as recipient and shadow banks as originator.

Figure 8 shows the yearly average amount of loans granted to households by the different counterpart categories. Loans to households doubled in nominal terms over the period 1999-2011, growing at high rates in the years preceding the financial crisis, and levelling off thereafter. Banks definitely dominate the picture with a share of $86 \%$ in 2013. However, the share of loans from shadow banks significantly increased from $4 \%$ in 1999 to $9 \%$ in 2013 (after a peak of $11 \%$ in 2009). However, the dynamics of MFIs' and shadow banks' loans over the crisis period suggests, prima facie, that there was not a significant substitution between the two sectors in the provision of long-term funding to households. ${ }^{9}$

A different picture characterizes the funding of NFCs (Fig. 9). The sources of loans are more heterogeneous and while traditional banks are still the most important provider of loans, their share declined from $59 \%$ in 1999 to just below $50 \%$ at the end of 2013. The share of funding through shadow banks instead increased noticeably since the eruption of the financial crisis: in 2006 the loans granted to NFCs by shadow banks were around $10 \%$, whereas at the end of 2013 the share was $15 \%$, suggesting a possible substitution among NFCs funding sources between traditional and shadow banks.

\footnotetext{
8 If we were to consider the whole resident sector (excluding MFIs) as the denominator of the shadow bank share, we would have a similar dynamics, but Luxembourg and the Netherlands would switch their relative positions, with Luxembourg being the country with the largest share of shadow banks.

9 As for the instrument of funding, while home mortgages represented only $61 \%$ of total loans in 1997, this share steadily increased throughout the period under examination, reaching the level of $74 \%$ in December 2014.
} 


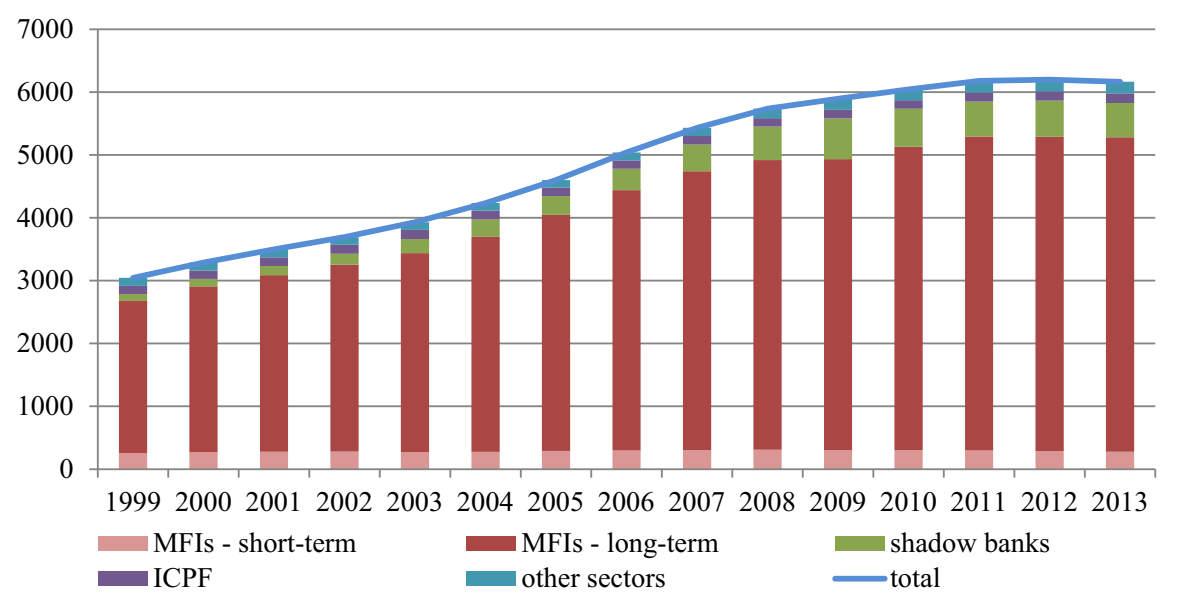

Fig. 8 Loans to households by counterpart (1) (billions of euros). Sources: ECB euro area accounts. (1) Loans to non-profit institutions serving households (NPISH) are also included. Shadow banks are proxied by the OFI sector

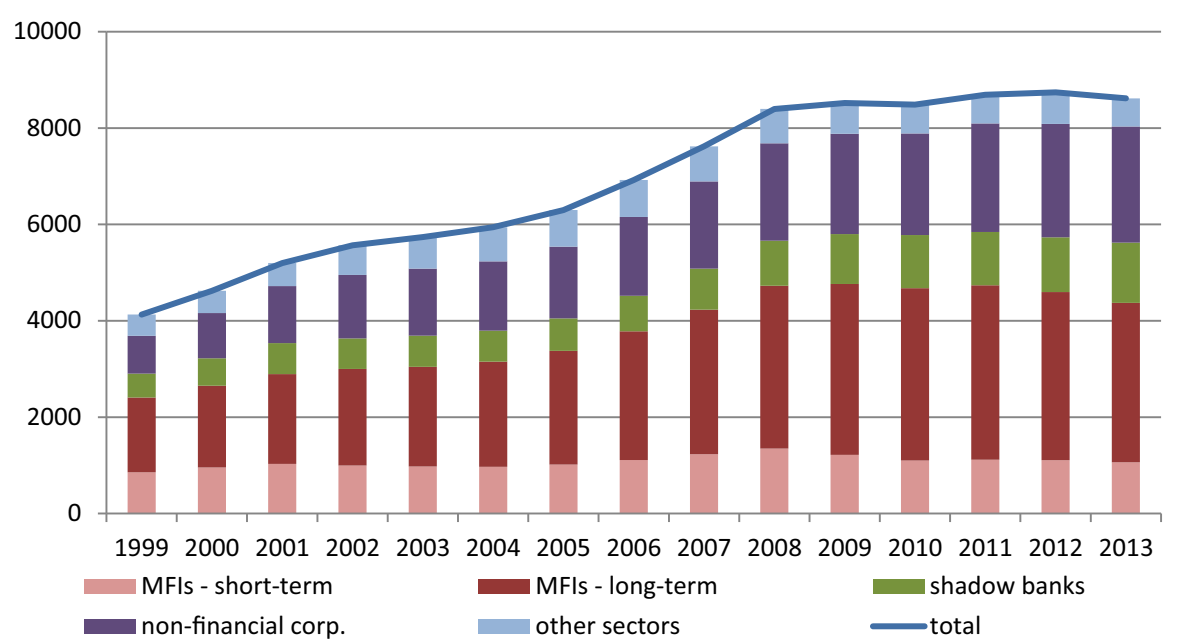

Fig. 9 Loans to NFCs by counterpart (1) (billions of euros). Sources: ECB euro area accounts. (1) Shadow banks are proxied by the OFI sector

In addition, two other significant developments are worth noting: the constant decline in the "other sectors" loans and the steady rise in loans from the non-financial sector itself. Within the other sectors aggregate we find foreign residents and the government. Since a peculiar feature of the crisis is the fragmentation along national borders of several financial market segments (see, e.g., CGFS 2011; Angelini et al. 2014; Zaghini 2016), the reduction in the NFCs' funding from abroad, even at the aggregate euro-area level, is not surprising. Its share declined from $12 \%$ in 2006 to just $7 \%$ in 2013 . 
The increase in loans from other NFCs is instead striking. While the share increased constantly over the sample period, it accelerated since 2010 . It was $19 \%$ in 1999 , it increased to $23 \%$ before the global financial crisis and peaked at $28 \%$ in 2013. Intrasectoral loans are thus a key source of finance for euro-area NFCs. The dynamics are most likely due to the widespread tightening of credit conditions put in place by euro-area MFI which pushed NFCs to look for other sources of funding both internal and external (ECB 2014). ${ }^{10}$

\subsection{Determinants of Loans to NFCs}

Given the relevance of changes in the funding opportunities for NFCs for the real economy, in this section we propose an analysis of the main determinants of the loans from shadows banks. ${ }^{11}$ In particular, the same model is estimated separately for both loans from banks and loans from shadow banks, in order to provide a first assessment of the differences among the two sectors as funding sources of euro-area firms.

Our reference model is taken from Errico et al. (2014), which provide a broad approach at estimating the different sources of funding for the NFCs headquartered in a set of global economies:

$$
\Delta \text { Loans }_{t}=\beta_{0}+\sum_{m=1}^{M} \beta_{m} V_{t, m}^{\text {market }}+\sum_{l=1}^{L} \beta_{l} V_{t, l}^{\text {global }}+\sum_{z=1}^{Z} \beta_{z} V_{t, z}^{\text {macro }}+\varepsilon_{t}
$$

where the dependent variable is the rate of growth in loans to NFCs provided by banks and shadow banks separately, measured quarterly over the period from 1999Q1 to 2014 Q1.

The set of regressors is made of variables from three groups: (i) variables identifying the structure of the domestic financial system; (ii) variables used as proxy for domestic and global liquidity conditions; (iii) a set of standard macro variables employed as controls for domestic demand and supply conditions. In particular, in the first group of variables we have the ratio of shadow banks' total asset to the sum of total assets by banks and shadow banks, and the ratio of total asset by ICPF over GDP as a measure of the role of the institutional investors in the economy and as a measure of the financial market development. ${ }^{12}$ In the second group we have: the market volatility indices (VSTOXX, VIX), a euro-area financial stress indicator [the Composite Indicator of Systemic Stress-CISS by Holló et al. (2012)] and the real effective exchange rate of the euro. Finally, as macro controls we employ the inflation rate (HICP and CPI rate of

\footnotetext{
10 Even though they are very different in nature and pose different issues as regards, for instance, debt sustainability, sector account concepts do not allow to distinguish between loans among corporations within the same group and loans among firms belonging to different groups (i.e. without a significant capital link).

11 Note that the loans to NFCs on shadow banks' balance sheet can be directly originated from shadow financial institutions or originated by traditional banks and then "transferred" via securitization to the shadow banking system.

12 The weight of ICPF is used, in particular, as control for the demand for shadow banking products from institutional investors.
} 
Table 2 Main determinants of loans to NFCs

\begin{tabular}{lcc}
\hline & Shadow banks & Banks \\
\hline Constant & $-97.165 *$ & $-15.532 * *$ \\
& 52.297 & 7.2848 \\
Real GDP growth & $5.0705 * * *$ & 0.2376 \\
& 1.2559 & 0.9854 \\
Inflation & $-14.202 * * *$ & -2.8786 \\
& 4.7509 & 2.3678 \\
Share of shadow & -0.6939 & $-0.8836 * * *$ \\
& 0.5192 & 0.2661 \\
ICPF weight & $0.8801 * *$ & $0.6496 * * *$ \\
& 0.3330 & 0.1888 \\
Term structure & $-3.1664 *$ & -0.7068 \\
& 1.7957 & 0.6870 \\
EONIA & $3.9888 *$ & $3.4632 * * *$ \\
& 2.4363 & 0.6005 \\
Volatility index & $-0.4985 * * *$ & -0.0518 \\
& 0.1431 & 0.0477 \\
REER & 0.1743 & -0.0675 \\
CISS & 0.2071 & 0.1367 \\
R-squared & 0.4637 & $-0.3228 * *$ \\
& 0.3577 & 0.1373 \\
& 0.619 & 0.902 \\
\hline
\end{tabular}

growth), GDP rate of growth, the ratio of government debt over GDP, the term spread (euro-area 10-year government benchmark bond yield less the 3-month EURIBOR), and a short-term rate (EONIA). All variables are sourced from the SDW dataset of the ECB.

Table 2 shows some relevant differences among the two sectors. While the rate of growth of loans from shadow banks tends to be influenced by macroeconomic conditions (GDP growth and inflation; column 1), bank loans are not (column 2), and they dependent only on market conditions (EONIA rate and the CISS market stress index) and the financial system structure (share of shadow banks' asset and relative weight of long-term institutional investors).

As for traditional banks, the ability of large players to rely on internal capital markets to manage cross-border liquidity can weaken the link between macroeconomic conditions and bank lending (Cetorelli and Goldberg 2012). For the opposite reasons, shadow banks, given their smaller dimension and clout, in addition to the lack of access to central bank money, may instead be significantly influenced by macroeconomic conditions and their credit intermediation function quickly altered.

As concerns the financial system structure, two facts stand out: first, since the coefficient on the ICPF weight is significant and positive for both regressions, it suggests that the increasing role of institutional investors (and thus a more mature financial system) is supportive of an expansion of the funding of the real economy, regard- 
less of the source. Second, there seems to be a likely crowding out effect at work: the coefficient on the share of shadow banks' assets is significant and negative for the traditional banking system, suggesting that when the role of shadow banks in the economy is growing the growth rate of loans originating from traditional banks is declining. Thus our results would go, at least partially, in the opposite direction with respect to the common view (shared in several regulatory fora) that in well-developed financial markets market-based finance can progress not at the expense of traditional banking finance.

At the same time, while the rate of growth of loans from both bank and shadow bank is influenced by the overnight rate, that of shadow bank alone is negatively influenced by the term structure. Given that the term structure can be thought of as a proxy of the lending rate, a negative correlation was ex-ante expected. However, this empirical evidence suggests that traditional banks are better equipped than shadow banks to tolerate changes in term structure without significantly affecting the growth of loans to the real economy.

Finally, for both traditional and shadow banks the growth rate of loans is negatively correlated with financial market sentiments (the volatility index for shadow bank, and the financial market stress index for banks). A context of high volatility and uncertainty is always associated to a lower growth of loans to NFCs.

All in all our results, though preliminary, show that in the euro area, over the period under analysis, the rate of growth of bank loans has been mainly driven by the financial system structure and market conditions whereas that of shadow banks has been influenced to a larger extent by demand-side factors as the macroeconomic conditions of the area.

\section{Conclusions}

Even though being under scrutiny because of its increasing role in financial markets, the shadow banking sector has a not yet a commonly agreed definition. We can well claim that the definition itself is shadowy. The term "shadow banking" was coined in a Fortune Magazine article in 2007 by Bill Gross, at the time president of Pimco, to highlight what was then described as "a secret banking system built on derivatives and untouched by regulation". This very first definition depicts shadow banking as a mysterious unregulated force in the financial system. However, even in 2012 the FED Chairman Bernanke (2012) did not propose a significant improvement in the definition when he stated that "Shadow banking, as usually defined, comprises a diverse set of institutions and markets that, collectively, carry out traditional banking functions-but do so outside, or in ways only loosely linked to, the traditional system of regulated depository institutions".

Thus a first aim of the paper is to shed light on the different definitions currently used. In this light we first review the rationale behind the two main approaches to the identification of shadow banking: the first being based on the activities undertaken by financial institutions, the second on the nature of the financial institutions involved in bank-like activities. 
Then, to fulfill our second aim, we employ one of such approaches to assess the size and development over time of the euro-area shadow banking system. In particular, we rely on the institution-based methodology proposed by ECB staff in Bakk-Simon et al. (2012). We find that, unlike the US, the shadow banking system in the euro area has always been far smaller than traditional banks. However, assets held by shadow banks are sizable and growing. According to the definition employed, the absolute size of the euro-area shadow banking system reached at the beginning of 2014 is even larger than the US counterpart. In addition, albeit data collected for the euro area still lack both details and coverage for a full understanding of the phenomenon, we also provide evidence of an increased interconnectedness between banks and shadowbanks, which has likely amplified the risk of contagion and which may pose a challenge for regulators. As a further warning for regulators, we provide evidence of a very large heterogeneity across euro-area countries as concerns both the system dimension and the interconnectedness with traditional banks.

Finally, as a key feature of the shadow banks we focus on their role of loans originator for the real economy. As a preliminary evidence, we find an increasing share of shadow banks in the funding of households and, to a larger extent, of NFCs. In fact, the share of loans originated from shadow banks to NFCs, even though starting from relatively small levels, has more than doubled since 1999. Then we provide an empirical analysis of the main drivers of loans to NFCs. Relying on a common basic model, we show that the main determinants of the growth rate of loans to NFCs from shadow banks and traditional banks differ significantly. While the former rate seems to be directly influenced by macroeconomic variables, the latter is not and it is mainly related to the financial system structure and the market mood.

In addition, we find that while the larger role played by long-term institutional investors (pension funds and insurance corporations) points to a backing of the funding of the economy by financial institutions (both traditional and shadow banks), we also find evidence of a possible crowding out effect: the growth rate of loans from traditional banks seems to decline when the relative role of shadow banks increases.

Acknowledgments The authors would like to thank Paolo Del Giovane, Giovanni Di Iasio, Lorenzo Esposito, Giuseppe Grande, Luigi Infante, Taneli Mäkinen and Giorgio Nuzzo for helpful discussions and useful suggestions. The paper was written while Fabrizio Malatesta was an intern at the Bank of Italy. The views expressed in the paper do not necessarily reflect those of the Bank of Italy and the European Commission.

\section{References}

Acharya V, Khandwala H, Öncü TS (2013) The growth of a shadow banking system in emerging markets: evidence from India. J Int Money Financ 39:207-230

Adrian T, Ashcraft AB (2012) Shadow banking: a review of the literature. Federal Reserve Bank of New York Staff Reports, No. 580

Adrian T, Shin H (2010a) The changing nature of financial intermediation and the financial crisis of 20072009. Annu Rev Econ 2:603-618

Adrian T, Shin H (2010b) Liquidity and leverage. J Financ Intermed 19(3):418-437

Adrian T, Ashcraft AB, Cetorelli N (2013) Shadow bank monitoring. Federal Reserve Bank of New York Staff Reports, No. 638 
Angelini P, Grande G, Panetta F (2014) The negative feedback loop between banks and sovereigns. Banca d'Italia Occasional Papers, No. 213

Bakk-Simon K, Borgioli S, Giron C, Hempell H, Maddaloni A, Recine F, Rosati S (2012) Shadow banking in the euro area: an overview. ECB Occasional Paper Series No. 133

Bernanke B (2012) Fostering financial stability. Speech held at the 2012 Federal Reserve bank of Atlanta Financial Markets Conference, Stone Mountain, Georgia. http://www.federalreserve.gov/newsevents/ speech/bernanke20120409a.htm

Borio C (2014) The financial cycle and macroeconomics: what have we learnt? J Bank Financ 45:182-198

Borio C, Disyatat P (2011) Global imbalances and the financial crisis: link or no link? BIS Working Paper Series No. 346

Bouveret A (2011) An assessment of the shadow banking sector in Europe. ESMA Working Paper

Cetorelli N, Goldberg LS (2012) Banking globalization and monetary transmission. J Financ 67(5):18111843

CGFS (2011) The impact of sovereign credi t risk on bank funding conditions. Committee on the Global Financial System, Paper No. 43

Claessens S, Ratnovki L (2014) What is shadow banking. IMF Working Paper No. 14/25

Eichner MJ, Kohn DL, Palumbo MG (2015) Financial statistics for the United States and the crisis: what did they get right, what did they miss, and how could they change? In: Hulten CR, Reinsdorf MB (eds) Measuring wealth and financial intermediation and their links to the real economy. NBER book series studies in income and wealth

Errico L, Harutyunyan A, Loukoianova E, Walton R, Korniyenko Y, Amidžić G, AbuShanab H, Shin HS (2014) Mapping the shadow banking system through a global flow of funds analysis. IMF Working Paper No. 14/10

European Central Bank, ECB (2014) Debt of non-financial corporations: consolidated and non-consolidated measures. Monthly Bulletin 50-53

European Commission, EC (2014) Economic review of the financial regulation agenda. Commission Staff Working Document

European Securities and Markets Authority, ESMA (2013) ESMA report on trends, risks, and vulnerabilities. No. 2

Fein ML (2013) The shadow banking charade. http://ssrn.com/abstract=2218812

Financial Stability Board, FSB (2011) Strengthening oversight and regulation of shadow banking. Consultative Document

Financial Stability Board, FSB (2014) Global shadow banking monitoring report

Gennaioli N, Shleifer A, Vishny RW (2013) A model of shadow banking. J Financ 68(4):1331-1363

Ghosh, S, Gonzalez del Mazo I, Ötker-Robe I (2012) Chasing the shadows: how significant is shadow banking in emerging markets? World Bank Economic Premise, Issue No. 88

Holló D, Kremer M, Lo Duca M (2012) CISS - a composite indicator of systemic stress in the financial system. ECB, WP Series, No. 1426

International Monetary Fund, IMF (2014) Shadow banking around the world: how large and how risky? Chapter 2, Global Financial Stability Report

Mishkin F (2006) How big a problem is too big to fail? J Econ Lit 44(4):988-1004

Meeks R, Nelson B, Alessandri P (2013) Shadow banks and macroeconomic instability. Banca d'Italia, Tema di Discussione No. 939

Pozsar Z, Adrian T, Ashcraft AB, Boesky H (2010) Shadow banking. Federal Reserve Bank of New York Staff Reports, No. 458

Pozsar Z, Adrian T, Ashcraft AB, Boesky H (2013) Shadow banking. FRBNY Econ Policy Rev 19(2):1-16 Singh M (2013a) The Changing Collateral Space. IMF Working Paper WP/13/25

Singh M (2013b) The economics of shadow banking. In: Health A, Lilley M, Manning M (eds) Liquidity and funding markets. 2013, Reserve Bank of Australia

Zaghini A (2016) Fragmentation and heterogeneity in the euro-area corporate bond market: back to normal? J Financ Stab 23:51-61 